\title{
ASSOCIATION OF INDAZIFLAM AND OXYFLUORFEN IN COFFEE PRE- TRANSPLANTATION
}

\author{
Laís Franchini Pucci ${ }^{1}$, Paulo Massaharu Fukada², Gustavo Antônio Mendes Pereira ${ }^{3}$, \\ Deivide Patrik Alves ${ }^{4}$, Carolina Alves Gomes ${ }^{5}$, Marcelo Rodrigues dos Reis ${ }^{6}$
}

(Received: May 29, 2019; accepted: July 11, 2019)

\begin{abstract}
Weed management in the pre-transplantation of coffee plants is an essential condition for the future success of the crop. Currently, the producer has few options to perform chemical management at this stage. Therefore, one of the solutions that is being used is the tank mixing of products proven efficient with new products on the market, such as indaziflam. The objective of this study is to know the selectivity of indaziflam, associated or not with oxyfluorfen, in coffee pre-planting and its effectiveness in weed control. Thus, the following treatments were tested in the field: indaziflam ( $25 \mathrm{~g} \mathrm{ha}^{-1}$ a.i. $)$, indaziflam (50 $\mathrm{g} \mathrm{ha}^{-1}$ a.i.), oxyfluorfen (960 $\mathrm{g} \mathrm{ha} \mathrm{h}^{-1}$ a.i. $)$, indaziflam $\left(25 \mathrm{~g} \mathrm{ha}^{-1}\right.$ a.i. $)+$ oxyfluorfen $\left(960 \mathrm{~g} \mathrm{ha}^{-1}\right.$ a.i. $)$, indaziflam $\left(50 \mathrm{~g} \mathrm{ha}^{-1} \mathrm{a} . \mathrm{i}.\right)+$ oxyfluorfen $\left(960 \mathrm{~g} \mathrm{ha}^{-1}\right.$ a.i.), plus a weeded and a non-weeded control. All treatments caused low intoxication in the seedlings, but without impairing the development and morphological variables of the plants. The treatments were efficient in controlling the species Bidens pilosa L., Commelina benghalensis L., Urochloa decumbens, Emilia fosbergii and Melampodium perfoliatum until 68 days after application. At 104 days, it was observed that there was a reduction in the efficiency of the products. It is concluded that the associated use of indaziflam and oxyfluorfen does not cause intoxications capable of interfering with the development of coffee plants. The association of these herbicides or their isolated applications is efficient in the control of weeds in the pre-transplantation of coffee plants, and the choice of the best management strategy is dependent on the weed community present in each area.
\end{abstract}

Index terms: Coffea arabica L., weed, herbicide, tank mixing.

\section{ASSOCIAÇÃO DE INDAZIFLAM E OXYFLUORFEN EM PRÉ-TRANSPLANTIO DE CAFÉ}

\begin{abstract}
RESUMO: O manejo de plantas daninhas em pré-transplantio de mudas de café é condição essencial para o sucesso futuro da lavoura. Hoje, o produtor dispõe de poucas opções para realizar o manejo químico nesta etapa. Com isto, uma das soluções que vem sendo empregada é a mistura em tanque de produtos comprovadamente eficientes com produtos novos no mercado, como o indaziflam. O objetivo do presente trabalho é conhecer a seletividade do indaziflam, associado ou não com oxyfluorfen, em pré-transplantio do café e sua eficácia no controle de plantas daninhas. Para isto, testou-se a campo, os seguintes tratamentos: indaziflam (25 $\mathrm{g} \mathrm{ha}^{-1}$ i.a.), indaziflam (50 $\mathrm{g} \mathrm{ha}^{-1}$ i.a.), oxyfluorfen $\left(960 \mathrm{~g} \mathrm{ha}^{-1}\right.$ i.a. $)$, indaziflam $\left(25 \mathrm{~g} \mathrm{ha}^{-1}\right.$ i.a. $)+$ oxyfluorfen (960 $\mathrm{g} \mathrm{ha}^{-1}$ i.a.), indaziflam (50 $\mathrm{g} \mathrm{ha}^{-1}$ i.a.) + oxyfluorfen ( $960 \mathrm{~g} \mathrm{ha}^{-1}$ i.a.), além de uma testemunha capinada e uma não capinada. Todos os tratamentos causaram baixa intoxicação nas mudas, sem prejudicarem o desenvolvimento e as variáveis morfológicas das plantas. Os tratamentos foram eficientes no controle das espécies predominantes na área, Bidens pilosa, Commelina benghalensis, Urochloa decumbens, Emilia fosbergii e Melampodium perfoliatum até os 68 dias após aplicação. Aos 104 dias observou-se que houve redução da eficácia dos produtos. Conclui-se que o uso associado ou não do indaziflam e do oxyfluorfen é seletivo em mudas de café. A associação destes herbicidas ou suas aplicações isoladas são eficientes no controle de plantas daninhas em pré-transplantio de mudas de café, sendo a escolha da melhor estratégia de manejo dependente da comunidade infestante presente em cada área.
\end{abstract}

Termos para indexação: Coffea arabica L., planta daninha, herbicida, mistura em tanque.

\section{INTRODUCTION}

Brazil is the world's largest coffee producer, exporter and consumer. It is estimated that the country has 2,209 hectares of planted area between the Arabica and Conilon species, and production of 49.67 million bags; Minas Gerais is the most active state, with 1,180 hectares planted and production of about 28.5 million bags per year (CONAB, 2019).

The success of coffee agribusiness is conditioned by the rational use of several production factors, such as fertilization (Burak et al., 2012; Serafim et al., 2011), irrigation (Martins et al., 2007; Oliveira et al., 2010) and phytosanitary management (Silva et al., 2018; Santos et al., 2014; Silva et al., 2012; Fernandes, 2009). In this context, weed management is extremely important, since it reduces the competition that weeds have with the crop by diverse growth factors, besides preserving the soil and extending the useful life of the coffee trees (Cogo et al., 2013; Alcãntara \& Ferreira, 2000).

1,2,3,4,5,6 Universidade Federal de Viçosa Campus Rio Paranaíba /UFV- CRP Instituto de Ciências Agrárias/ IAP - Km 7 - Zona Rural MG-230 - Rodoviario - Rio Paranaíba - MG, 38810-000- Rio Paranaíba - MG- paulo.fukada95@gmail.com, laisfpucci@gmail.com, gustavogamp@hotmail.com, deividepatrikalves123@gmail.com, carol.agomes11@gmail.com, marceloreis@ufv.br 
Weed infestation in coffee plantations can result in losses to the producer, as both compete for water and nutrients for their growth and development (Agostinetto et al., 2008). Within the production system, it is necessary to know the weed species that are most frequent, in order to carry out an adequate control recommendation (Rocha et al., 2017).

Newly transplanted coffee seedlings lead to a reduced soil shading condition, especially due to the size of the young plant, which favors weed emergence (Fialho et al., 2011). In addition, coffee seedlings show sensitivity to the various active ingredients of herbicides registered for crop, making it difficult to handle weeds at the beginning of the cycle.

Currently, the number of herbicides registered for use in coffee is very limited (MAPA, 2019), and the use of mechanical practices, such as the use of brushcutters and manual weeding, are of high cost and low efficiency. In this context, chemical control in coffee trees has been performed with repeated applications of glyphosate and oxyfluorfen (Magalhães et al., 2012). Thus, the absence of rotation of action mechanisms in coffee plants is of concern, since it can lead to the selection of tolerant and/or biotypes resistant weeds, caused by the intensive use of herbicides, as already observed for several species with the use of glyphosate (Christoffoleti and Nicolai, 2016). In the case of oxyfluorfen, in recent years, several producers have reported that this product has presented a loss of efficiency, however without scientific proof so far. The physicochemical characteristics of the molecules are important to understand its behavior in the soil, especially its persistence in the control of weeds (Pereira et al., 2018).

The herbicide indaziflam is a new alternative for use in coffee plantations. It was introduced in the Brazilian market in 2016, is a product used in pre-emergence, registered for weed control also in sugarcane crops and fruit plantations. It belongs to the chemical group alkylazine, presenting a broad spectrum of action and long-lasting action, besides efficiency with low dose applications (Silva et. al., 2017; Guerra et al., 2013).

With the recent normative instruction No. 40, dated October 11, 2018 (MAPA, 2019), the use of herbicides in tank mixing will be an increasingly used practice by producers, but lacking studies that prove the effectiveness of these mixtures over weed control, possible damage to crops of interest and risks to successor crops. The hypothesis of this study is to verify if the herbicides oxyfluorfen and indaziflam can be used or not mixed in the tank, without loss of efficiency, besides making a parallel between the products with respect to the spectrum of weed control and the time in which they remain active in the soil, controlling weeds.

In this way, the objective of this research was to assess the selectivity of indaziflam, associated or not with oxyfluorfen, in coffee pre-transplantition and its effectiveness in weed control.

\section{MATERIAL AND METHODS}

The experiment was carried out in the field on the Donanas farm, located in the municipality of Rio Paranaíba-MG (19 $12^{\prime} 37.40^{\prime \prime} \mathrm{S}$, $\left.46^{\circ} 7^{\prime} 58.44^{\prime \prime} \mathrm{O}\right)$, at 1124 meters altitude. The average temperature of the region is $20.4{ }^{\circ} \mathrm{C}$ and the average annual rainfall is $1533 \mathrm{~mm}$, the climate of the region is classified as Cwa (CPRM, 2019).

The experiment was set on December 25, 2017, using 'Topázio' coffee (Coffea arabica L.), cultivated at spacing of $3.6 \mathrm{~m}$ between rows and $0.5 \mathrm{~m}$ between plants, totaling a population of 5,555 plants ha ${ }^{-1}$.

The treatments consisted of the application of the herbicides at the respective doses: indaziflam (25 $\mathrm{g} \mathrm{ha}^{-1}$ a.i.), indaziflam (50 $\mathrm{g} \mathrm{ha}^{-1}$ a.i.), oxyfluorfen ( $960 \mathrm{~g} \mathrm{ha}^{-1}$ a.i.), indaziflam ( $25 \mathrm{~g}$ ha $^{-1}$ a.i.) + oxyfluorfen ( $960 \mathrm{~g} \mathrm{ha}^{-1}$ a.i. $)$, indaziflam (50 $\mathrm{g} \mathrm{ha}^{-1}$ a.i.) + oxyfluorfen (960 $\mathrm{g} \mathrm{ha}^{-1}$ a.i.), as well as a weeded and a non-weeded control. The following trademarks were used: Alion ${ }^{\circledR}$ and Goal ${ }^{\circledR}$. The experimental design was in randomized blocks, with four replicates, totaling 28 experimental plots $\left(8 \mathrm{~m}^{2}\right)$. The seedlings were spaced at 3.5 meters between rows and $50 \mathrm{~cm}$ between plants.

The treatments were applied in coffee preemergence, before transplanting the seedlings. A costal electric sprayer, coupled to $2 \mathrm{~L}$ bottles, equipped with dual fan tips (TT 11002), was used for the application. The established flow rate was $200 \mathrm{~L} \mathrm{ha}^{-1}$ nozzle, at a range of $0.5 \mathrm{~m}$ on each side of the planting line, so that the planting line does not receive the herbicide. Two days after application (DAA), the seedlings were transplanted. The seedlings were standardized with 3 pairs of fully expanded leaves.

At 30, 68 and 104 DAA, the control spectrum of the products was evaluated on the following weeds: "picão preto" (Bidens pilosa L.), "trapoeraba" (Commelina benghalensis L.), 
signalgrass (Urochloa decumbens), "falsa serralha" (Emilia fosbergii) and "estrelinha" (Melampodium perfoliatum), plants commonly found in coffee plantations and of greater abundance in the area. This evaluation was performed using a square of $0.5 \times 0.5 \mathrm{~m}\left(0.25 \mathrm{~m}^{2}\right)$ that was randomly launched twice in a representative area of each plot and the target weeds were then identified and evaluated the percentage of control (Barcellos Júnior et al., 2016). At 30, 68 and 104 DAA were also evaluated the intoxication caused in plants, according to the grading scale proposed by the Brazilian Society of Weed Science (SBCPD, 1995), where 0\% represents no injury to plants and $100 \%$, total death.

At 71 DAA, plant height was measured up to the second bud, and stem diameter, two centimeters of the soil surface of 6 plants per plot, using a $300-\mathrm{mm}$ digital caliper (Digimess).

Data on the variables weed control and intoxication of coffee plants were submitted to descriptive analysis and presented in the form of bar charts, with their respective standard deviations. The morphological variables plant height and diameter were submitted to analysis of variance and, for the significant factors, the means were compared by the Tukey test $(p<0.05)$. The Speed Stat ${ }^{\mathbb{R}}$ software was used for statistical analyses and Sigmaplot $12.0^{\circledR}$ for graphing.

\section{RESULTS AND DISCUSSION}

There was low intoxication of coffee plants in all the treatments to which they were submitted (Figure 1). At 30 DAA, it was observed that the isolated use of oxyfluorfen, and its association with the two doses of indaziflam, were the treatments that caused the most damage to the seedlings. However, in none of the treatments did severe intoxications occur, up to $20 \%$, which is agronomically acceptable, since the plants are able to recover from the damage (Paiva et al., 2015). At 68 and 104 DAA, it was observed that there was a gradual reduction in the symptoms, with percentages lower than $3 \%$, in the last evaluation.

The presence of oxyflorfen isolatedly in the soil caused symptoms, initially the appearance of leaf burns and dark green spots was observed which, according to Rodrigues and Almeida (2011), can be explained by the rupture of the cell membrane and, consequently, the extravasation of the cytoplasmic fluid in the cellular intervals.

In a study about tolerance of coffee seedlings to post-emergence herbicides, observed that the herbicide oxyfluorfen, applied directly under the plants, also caused phytotoxic effects on the plants, characterized by burns and deformations throughout the blade leaf area reached (Ronchi \& Silva, 2003). In a study also working with oxyfluorfen in pre-emergence, describe that this characteristic was more present in new leaves and in points of intense growth, as in new shoots and in the apical meristem, while in the older leaves, the most predominant symptom was the appearance of chlorotic points (Silva et al., 2017).

The seedlings treated with indaziflam isolated were less intoxicated, when compared to the herbicide oxyfluorfen. On the other hand, when this herbicide was associated with oxyfluorfen, it was observed that the intoxications were similar to those observed for oxyfluorfen alone, regardless of the evaluation period.

Indaziflam interrupts the formation of crystals in the cell wall, with no new leaves appearing, but the fully developed leaves will hardly be affected by indaziflam, since cell wall formation is already completed and no new cellulose synthesis occurs (Guerra et al., 2013), justifying the smallest symptoms observed by this herbicide.

At 71 DAA, no change was observed in the height and diameter of coffee plants with the exposure of the treatments (Table 1).

At 30 DAA all treatments were efficient in controlling weeds B. pilosa, E. fosbergii and $M$. perfoliatum, with control percentages close to $100 \%$ (Figure 2) and this efficiency was maintained until 104 DAA. Magalhães et al. (2012) also observed satisfactory oxyfluorfen control over Emilia fosbergii, Sida glaziovii and $S$. rhombifolia in the implantation of the coffee crop, however these authors evaluated the action of this herbicide only up to 75 DAA.

The application of indaziflam isolated at both doses, resulted in the control of $C$. benghalensis in average below $80 \%$ from 30 DAA considered unsatisfactory. $C$. benghalensis is a difficult-to-control plant due to its tolerance to glyphosate the main herbicide used in coffee plantations (Oliveira et al., 2009). Lorenzi (2008) describes it as a perennial, herbaceous and very frequent weed in crops in addition to being among the species that compete the most with the coffee crop (Oliveira et al., 2005).

The use of oxyfluorfen and its mixtures with indaziflam, led to the control near $100 \%$ of $C$. benghalensis up to 68 DAA. However, at 104 DAA, a reduction in control efficiency was observed, reaching average values close to $70 \%$. 


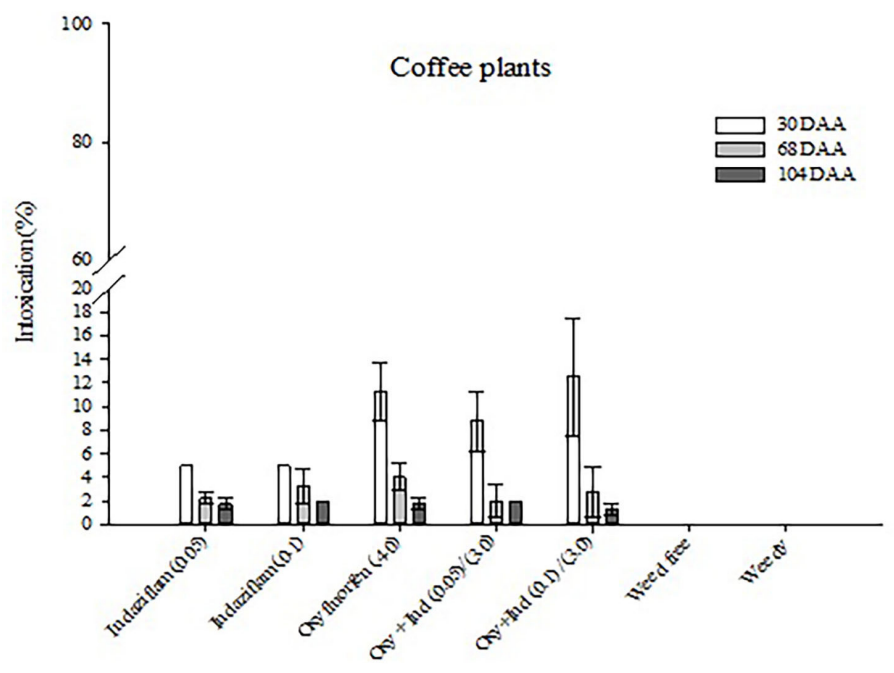

FIGURE 1 - Intoxication of coffee plants submitted to different associations of herbicides in pre-transplanting.

TABLE 1 - Measure of coffee plant diameter and height at 71 days after application of treatments with herbicides.

\begin{tabular}{|c|c|c|}
\hline Treatments & Diameter $(\mathbf{m m})$ & Height (cm) \\
\hline Indaziflam $\left(25\right.$ g a.i. ha $\left.{ }^{-1}\right)$ & 4.4 & 5.1 \\
\hline Indaziflam (50 g a.i. ha-1) & 4.1 & 4.0 \\
\hline Oxyfluorfen (960 g a.i. ha $\left.{ }^{-1}\right)$ & 4.4 & 3.7 \\
\hline Oxy + Ind $(25 \mathrm{~g} / 960 \mathrm{~g} \text { a.i. ha-1 })^{-12}$ & 4.1 & 4.1 \\
\hline Oxy+Ind $\left(50 \mathrm{~g} / 960 \mathrm{~g} \text { a.i. ha }{ }^{-1}\right)^{/ 2}$ & 4.3 & 4.4 \\
\hline Weed free & 3.7 & 5.7 \\
\hline Weedy & 3.8 & 5.0 \\
\hline Average & 4.1 & 4.6 \\
\hline C.V. $(\%)$ & 13.11 & 25.55 \\
\hline Test F & $1.31 * S / 1$ & $1.46 * \$$ \\
\hline
\end{tabular}

According to Magalhães et al. (2012), 75 DAA is the time that practically ends the expected period for the residual effect of oxyfluorfen. Being this time of control depends on factors related to the soil and the climate of the region (Silva \& Silva, 2013).

The control of $U$. decumbens was satisfactory (above 80\%) with the use of all treatments up to 68 DAA, with emphasis on the use of the highest dose of indaziflam and oxyfluorfem alone and in a mixture, which obtained controls close to $100 \%$. At 104 DAA, it was observed that all the treatments lost effectiveness, with values lower than the considered satisfactory. This fact may be related to soil and climatic factors that may alter herbicide availability for weed control (Chagas et al., 2019).

The application of indaziflam $\left(60 \mathrm{~g} \mathrm{ha}^{-1}\right)$ in pre-emergence of annual grasses presented 80 and $90 \%$ control of grass growth, analyzed at 195 DAA (Brosnan et al., 2011; Brosnan et al., 2012; Perry et al.; 2011). Other studies conducted in Brazil also demonstrated that the application of indaziflam at doses above $100 \mathrm{~g} \mathrm{ha}^{-1}$ in pre-emergence of the species Ageratum conyzoides, Sida rhombifolia and Digitaria horizontalis. yielded satisfactory control for a period up to 120 days after application (Christoffoleti \& Nicolai et al., 2016). 

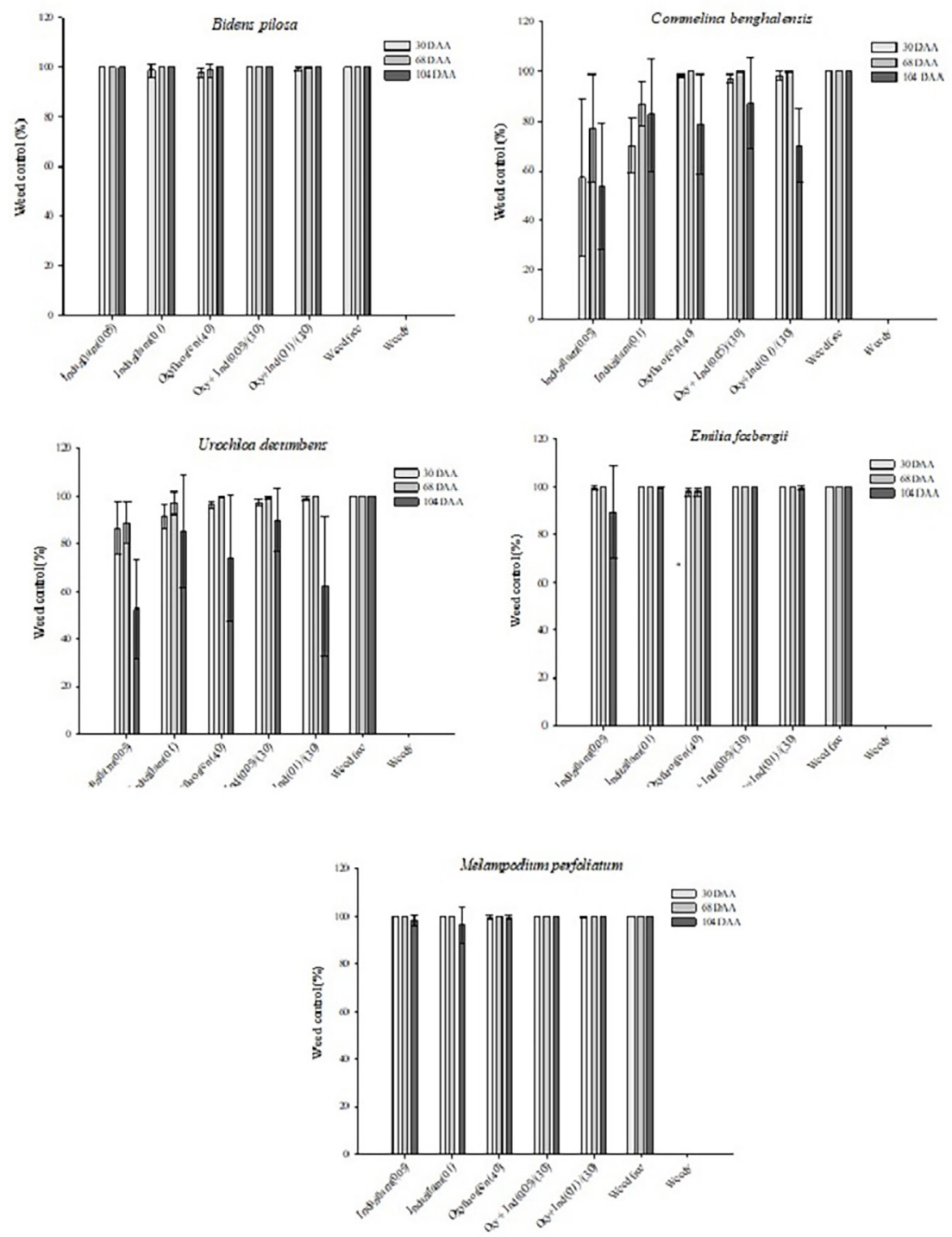

FIGURE 2 - Weed control percentage: Bidens pilosa L., Commelina benghalensis L., Urochloa decumbens, Emilia fosbergii and Melampodium perfoliatum submitted to different associations of herbicides in pre-transplantation of coffee plants.

In study about the consequences of noncontrol of $U$. decumbens, that can cause a reduction in coffee growth, even at low densities (Fialho et al., 2011 and Fialho et al., 2010). The authors further state that it is characteristic of $\mathrm{C}_{4}$ metabolism species, such as grasses. to become highly competitive with $\mathrm{C}_{3}$ species, such as coffee, mainly due to rapid growth and shading capacity in the early development stages.

The results of this research indicated the possibility of using any of the isolated products and mixtures tested, which increases the possibility of rotation of action mechanisms and spectrum of weed control in the pre-transplantation management of coffee plants.

\section{CONCLUSIONS}

The associated use or not of indaziflam and oxyfluorfen does not cause intoxications in coffee plants.

The association of these herbicides or their isolated applications is effective in weed control in the pre-transplantation of coffee plants. The choice of the best management strategy is dependent on the weed community present in each area.

\section{REFERENCES}

AGOSTINETTO, D. et al. Período crítico de competição de plantas daninhas com a cultura do trigo. Planta daninha, Viçosa, v. 26, n. 2, p. 271-278, mar. 2008. 
ALCÂNTARA E. N.; FERREIRA, M. M. Efeito de métodos de controle de plantas daninhas na cultura do cafeeiro sobre a qualidade física do solo. Revista Brasileira de Ciência do Solo, Viçosa, v. 24, n.4, p. 711-721, jun. 2000.

BARCELLOS JÚNIOR, L. H. et al. Fitossociologia de plantas daninhas em cultivos de feijão sobre diferentes manejos de herbicidas. Revista Brasileira de Herbicidas, Londrina, v. 15, p. 221-231, 2016.

BROSNAN, J. T. et al. PRE and POST control of annual bluegrass (Poa annua) with indaziflam. Weed Technology, Fayetteville, v. 26, n. 1, p. 48-53, 2012.

BROSNAN, J. T. et al. Smooth crabgrass control with indaziflam at various spring timings. Weed Technology, Fayetteville, v. 25, n. 3, p. 363-366, 2011.

BURAK, D. L.; PASSOS, R. R.; ANDRADE, F. V. Variabilidade espacial de atributos químicos do solo sob cafeeiro Conilon: relação com textura, matéria orgânica e relevo. Bragantia, Campinas, v. 71, n. 4, p.538-547, dez. 2012.

CHAGAS, P. S. F. et al. Multivariate analysis reveals significant diuron-related changes in the soil composition of different Brazilian regions. Scientific Reports, Minneapolis, v. 9, p. 1-12, 2019.

CHRISTOFFOLETI, P. J.; NICOLAI M. Aspectos de resistência de plantas daninhas a herbicidas. Piracicaba: Associação Brasileira de Ação à Resistência de Plantas Daninhas aos Herbicidas, 2016, 262 p.

COGO, F. D. et al. Estoques de carbono orgânico do solo em cafezais sob diferentes sistemas de controle de plantas invasoras. Semina: Ciências Agrárias, Londrina, v. 34, n. 3, p. 1089-1098, mai./jun. 2013.

CONAB. COMPANHIA NACIONAL DE ABASTECIMENTO. Available on: <http://www. sapec.embrapa.br/arquivos/consorcio/levantamento/ conab_safra2018_n4.pdf.>Acessed: Apr. 26, 2019.

CPRM - SERVIÇO GEOLÓGICO DO BRASIL. Serviço geológico do Brasil: relatório do ano de 2007. Brasília: [s.n.], 2008. Disponível em: <http:// www.cprm.gov.br/ publique/media/rel_anual_2007. pdf/>. Acesso em: 28 jun. 2019.

FERNANDES, A. L. T. et al. Utilização do silício no controle de pragas e doenças do cafeeiro irrigado. FAZU em Revista, Uberaba, n. 6, p. 11-52, 2009.
FIALHO, C. M. T. et al. Competição de plantas daninhas com a cultura do café em duas épocas de infestação. Planta Daninha, Viçosa, v. 28, n. especial p. 969-978, dez. 2010.

FIALHO, C. M. T. et al. Interferência de plantas daninhas sobre o crescimento inicial de Coffea arabica. Planta Daninha, Viçosa, v. 29, n. 1, p. 137-147, fev. 2011.

GUERRA, N. et al. Aminocyclopyrachlor e indaziflam: Seletividade, controle e comportamento no ambiente. Revista Brasileira de Herbicidas, Londrina, v. 12, n. 3, p. 285-295, set. /dez. 2013.

LORENZI, H. Plantas daninhas do Brasil: terrestres, aquáticas, parasitas, tóxicas e medicinais. Nova Odessa: Instituto Plantarum, 2008, 608 p.

MAGALHÃES, C. E. O. et al. Seletividade e controle de plantas daninhas com oxyfluorfen e sulfentrazone na implantação de lavoura de café. Planta Daninha, Viçosa, v. 30, n. 3, p. 607-616, mai. 2012.

MAPA. MINISTÉRIO DE AGRICULTURA PECUÁRIA E ABASTECIMENTO. Available on: < http://www.agricultura.gov.br/assuntos/ insumos-agropecuarios/insumos-pecuarios/produtosveterinarios/legislacao-1/instrucoes-normativas $>$ Acessed: Apr. 26, 2019.

MAPA. MINISTÉRIO DE AGRICULTURA PECUÁRIA E ABASTECIMENTO. Available on: $<$ http://www.agricultura.gov.br/assuntos/insumosagropecuarios/insumos-agricolas/agrotoxicos/agrofit $>$ Acessed: Jun. 28, 2019.

MARTINS, C. C. et al. Manejo da irrigação por gotejamento no cafeeiro (Coffea arabica L.). Bioscience Journal, Uberlândia, v. 23, n. 2, p. 61-69, apr. /jun. 2007.

OLIVEIRA E. L. et al. Manejo e viabilidade econômica da irrigação por gotejamento na cultura do cafeeiro acaiá considerando seis safras. Engenharia Agrícola, Jaboticabal, v.30, n.5, p.887-896, set. /out. 2010.

OLIVEIRA, A. R. et al. Controle de Commelina benghalensis, C. erecta e Tripogandra diuretica na cultura do café. Planta Daninha, Viçosa, v. 27, n. 4, p. 823-830, 2009.

OLIVEIRA, A. R.; FREITAS, S. P.; VIEIRA, H. R. Interferência de trapoerabas no desenvolvimento de mudas de café. Agronomia, Seropédica, v. 39, n. 1-2, p. 17-21, 2005. 
PAIVA, M. C. G. et al. Phytotoxicity of herbicides applied in post transplanting of seedlings of yellow passion fruit. Revista Brasileira de Herbicidas, Londrina, v.14, n.4, p.280-287, out./dez. 2015.

PEREIRA, G. A. M. et al. Sorption and desorption behavior of herbicide clomazone in soils from Brazil. Bioscience Journal, Uberlândia, v. 34, p. 1496-1504, 2018.

PERRY, D. $H$. et al. Indaziflam utilization for controlling problematic turfgrass weeds. Applied Turfgrass Science, Madison, v. 8, n. 1, p. 1-7, 2011.

ROCHA, R. S. et al. Levantamento Fitossociológico de Plantas Daninhas em Lavouras de Café Arábica com Diferentes espaçamentos In: ANAIS DA SEMANA ACADÊMICA DO CURSO DE AGRONOMIA DO CCAE/UFES, 28, 2017, Alegre, Anais eletrônicos... Alegre: Universidade Federal do Espírito Santo, 2017. Available: < http://periodicos.ufes.br/SEAGRO/ article/view/17412/11966>. Accessed in: Mai. 21, 2019.

RODRIGUES, B. N.; ALMEIDA, F.S. Guia de herbicidas. Londrina: IAPAR, 2011. 697 p.

RONCHI, C. P.; SILVA, A. A. Tolerância de mudas de café a herbicidas aplicados em pós-emergência. Planta Daninha, Viçosa, v. 21, n. 3, p. 421-426, 2003.

SANTOS, L. S. D. et al. Incidência da mancha de phoma em cafeeiro irrigado por gotejamento, sob diferentes manejos de irrigação. Coffee Science, Lavras, v. 9, n. 1, p. 77-89, jan./ mar. 2014.
SERAFIM, M. E. et al. Sistema conservacionista e de manejo intensivo do solo no cultivo de cafeeiros na região do Alto São Francisco, MG: Um estudo de caso. Bioscience Journal, Uberlândia, v. 27, n. 6, p. 964977, nov./ dez. 2011.

SILVA, C. A. et al. Chemical control of Conyza canadensis (L.), in mixtures of herbicides with glyphosate in coffee crop. Coffee Science, Lavras, v. 13, n. 2, p. 252 - 256, apr./ jun. 2018.

SILVA, J.; JUCKSCH, I.; TAVARES, R. C. Invertebrados edáficos em diferentes sistemas de manejo do cafeeiro na Zona da Mata de Minas Gerais. Revista Brasileira de Agroecologia, Pelotas, v.7, n.2, p. 112-125, fev. 2012.

SILVA, V. F. V.et al. Uso do Novo Herbicida Indaziflam em Pomares de Banana. Revista Brasileira de Herbicidas, Londrina, v.16, n.4, p.325-332, out./dez. 2017.

SILVA, A. A., SILVA, J. F. Tópicos em manejo de plantas daninhas. Viçosa: Universidade Federal de Viçosa, 2013, 367p.

SOCIEDADE BRASILEIRA DA CIÊNCIA DAS PLANTAS DANINHAS. Procedimentos para instalação, avaliação e análise de experimentos com herbicidas. Londrina: SBCPD, 1995, 42 p. 